\title{
Physio-Chemical Properties of Bamboo Genetic Resources at Various Age Gradations
}

\author{
R. Thirunirai Selvan", K.T. Parthiban and S. Umesh Khanna
}

Forest College and Research Institute, Tamil Nadu Agricultural University, Mettupalayam - 641 301, Tamil Nadu, India

*Corresponding author

\author{
A B S T R A C T
}

\begin{tabular}{|l|}
\hline Ke y w o r d s \\
Physio-chemical \\
properties, Moisture \\
content, \\
Holocellulose, \\
Lignin, Age- \\
gradation, Bamboo.
\end{tabular}

Keywords

Physio-chemical properties, Moisture gradation, Bamboo.

Accepted:

Available Online:

10 September 2017
Five age gradations of seven Bamboo species viz., Bambusa bambos, Dendrocalamus strictus, Bambusa vulgaris var. vulgaris, Bambusa vulgaris var. striata, Bambusa balcooa, Bambusa tulda and Bambusa polymorpha were subjected to physical and chemical analysis in order to recommend suitable species at reasonable rotation age for pulp and paper production. All the five age gradations exhibited considerable differences for physical and chemical properties in Bamboo genetic resources. Considering physical properties viz., bulk and basic density, all the age gradation were moderate to high in range which indicated their suitability as pulpwood. In proximate analysis, characters viz., Ash content, Hot water solubility, $1 \% \mathrm{NaOH}$ Solubility, Alcohol benzene extractives, Acid insoluble lignin, Pentosans and Hollocellulose were analysed. The different age gradations of various bamboo genetic resources differ significantly for holocellulose, which constitutes the cellulose and hemi-cellulose (essential factors for paper production). Among the five age gradations, the superiority of five-year-old Bambusa balcooa was evident due to maximum holocellulose content, low ash content and moderate the lignin content.

\section{Introduction}

Bamboos form one of the very important natural resources playing a major role in the livelihood of the rural people and in the rural industry. They also act as a source of raw material for cottage industry in rural areas and in pulp and paper industry (Negi, 1996). The demand for industrial wood raw material is increasing due to expansion of various paper mills. Considering the widening gap between demand and supply, almost all industries in the country are in the process of establishment of industrial wood plantation (Lal, 2000). Moreover, characterization of bamboo in relation to its physical, chemical properties helps to determine the maturation age towards better processing and utilization. Liese (1997) reported that properties and utilization of bamboos are influenced by structural changes brought about by aging. The relation between bamboo aging and maturation was reviewed by Liese and Weiner (1996). Researchers such as Zhou (1981), Espiloy (1987), Widjaja and Risyad (1987) and Abd Latif et al., (1990) as well as Sattar et al., (1994) are in general agreement that bamboo culm matures at two to three years, reaching its maximum strength. However, this general agreement did not include overall properties of individual 
bamboo species. In subtropical countries such as China, bamboo properties have been reported to differ with species, age, location and external factors (Anon., 2001). Therefore, studies on its physical and chemical properties should be geared towards harvesting bamboo at the most suitable age to ensure superior quality. Systematic characterization of these properties would help the industry in terms of utilization. However, such systematic studies are dismally modest in bamboo genetic resources.

\section{Materials and Methods}

The pulping experiments were carried out to find out its suitability for paper making at Research and Development laboratory of Tamil Nadu Newsprint and Paper Ltd. (TNPL), Kagithapuram, Karur during 20112012. Physical properties viz., Moisture content, Bulk density, basic density (Haygreen and Bowyer, 1982) and Chips classification were analysed as per TAPPI methods (TAPPI, 1980)

The billets of individual tree species were chipped in pilot chipper; air-dried and converted into wood meal in a laboratory Wiley disintegrator. The wood dust passing through 40 mesh but retained over 60 mesh was subjected to analysis for moisture, ash, hot water soluble, one per cent $\mathrm{NaOH}$ soluble, AB extractive, acid insoluble lignin, pentosans, holocellulose as per TAPPI methods (TAPPI, 1980).

\section{Results and Discussion}

\section{Physical properties of wood chips}

The physical properties viz., Moisture content, bulk density and basic density were analysed along with moisture content for seven Bamboo species with different age gradations (Table 1).
Moisture content of wood samples derived from various bamboo genetic resources as well as across the various age gradations was compared with Bambusa bambos and Dendrocalamus strictus as control. Among the various Bamboo species Bambusa polymorpha has the highest moisture content in all age gradations viz., first year $(68.14 \%)$, second year $(62.48 \%)$, third year $(56.85 \%)$, fourth year $(51.78 \%)$ and fifth year (36.14 $\%$ ). Followed by Bambusa balcooa, Bambusa vulgaris var. vulgaris had registered the next highest moisture content. The lowest moisture content was observed in the all age gradations of Bambusa vulgaris var. striata.

One year old Bambusa tulda has recorded the highest Bulk density (186.00 $\mathrm{kg} \mathrm{m}^{-3}$ ) among various bamboo species. All other age gradations of Bambusa tulda scored higher value than the other species viz., two $\left(194.00 \mathrm{~kg} \mathrm{~m}^{-3}\right)$, three $\left(206.00 \mathrm{~kg} \mathrm{~m}^{-3}\right)$, four $\left(212.00 \mathrm{~kg} \mathrm{~m}^{-3}\right)$ and five-year-old $(225.00 \mathrm{~kg}$ $\mathrm{m}^{-3}$ ) followed by the age gradations of Bambusa balcooa recorded the highest bulk density viz., one $\left(179.00 \mathrm{~kg} \mathrm{~m}^{-3}\right)$, two $(186.00$ $\left.\mathrm{kg} \mathrm{m}^{-3}\right)$, three $\left(195.00 \mathrm{~kg} \mathrm{~m}^{-3}\right)$, four $(207.00$ $\mathrm{kg} \mathrm{m}^{-3}$ ) and five-year-old $\left(218.00 \mathrm{~kg} \mathrm{~m}^{-3}\right)$. It shows increases in bulk density with the increase in age.

Basic density has recorded highest value in five year old Bambusa tulda species (482.00 $\mathrm{kg} \mathrm{m}^{-3}$ ) compared to control at this age gradation. All other age gradations of Bambusa tulda has highest value than the grand mean viz., one $\left(431.20 \mathrm{~kg} \mathrm{~m}^{-3}\right)$, two $\left(446.80 \mathrm{~kg} \mathrm{~m}^{-3}\right)$, three $\left(468.20 \mathrm{~kg} \mathrm{~m}^{-3}\right)$ and four-year-old $\left(475.10 \mathrm{~kg} \mathrm{~m}^{-3}\right)$ followed by the age gradations of Bambusa balcooa viz., one $\left(428.00 \mathrm{~kg} \mathrm{~m}^{-3}\right)$, two $\left(442.00 \mathrm{~kg} \mathrm{~m}^{-3}\right)$, three $\left(466.00 \mathrm{~kg} \mathrm{~m}^{-3}\right)$, four $\left(472.00 \mathrm{~kg} \mathrm{~m}^{-3}\right)$ and five-year-old $\left(480.90 \mathrm{~kg} \mathrm{~m}^{-3}\right)$ showed highest basic density among the other bamboo species. The lowest value was observed in the age gradations of Bambusa vulgaris var. 
striata viz., one $\left(390.00 \mathrm{~kg} \mathrm{~m}^{-3}\right)$, two $(410.00$ $\left.\mathrm{kg} \mathrm{m}^{-3}\right)$, three $\left(435.00 \mathrm{~kg} \mathrm{~m}^{-3}\right)$, four $(445.00$ $\mathrm{kg} \mathrm{m}^{-3}$ ) and five-year-old $\left(450.00 \mathrm{~kg} \mathrm{~m}^{-3}\right)$. This reveals that basic density is increasing with the increase in age.

\section{Chemical properties}

The alcohol-benzene solubility of wood constitutes the waxes, fats and resinous matter. The data obtained showed that the extractives were in the range of 4.22 per cent (Bambusa vulgaris var. striata) to 1.22 per cent (Dendrocalamus strictus) in the fiveyear-old bamboo species and five-year age gradation showed higher alcohol - benzene extractive than the other age gradations. In the overview Bambusa vulgaris var. striata age gradations has the highest alcohol-benzene extract viz., one (1.05\%), two (2.87\%), three $(3.12 \%)$ and four-year-old $(3.90 \%)$ than the control.

Hot water solubility was found to be maximum in one-year-old Bamboo species and minimum in five-year-old Bamboo species. While comparing five-year-old bamboo species with the control $(4.82 \%)$, Bambusa polymorpha $(6.88 \%)$ has the highest value than other bamboo species. The lowest value is observed in Bambusa tulda $(1.30 \%)$. Within the age gradations of Bamboo species, Bambusa polymorpha age gradations shows the highest value viz., one $(9.82 \%)$, two $(8.94 \%)$, three $(8.34 \%)$ and four-year-old $(7.48 \%)$ than the control (Table 2).

A maximum value of one per cent $\mathrm{NaOH}$ solubility was recorded in five-year-old Bambusa vulgaris var. striata $(33.13 \%)$ and minimum in five-year-old Bambusa polymorpha (18.39\%). Among the age gradations, Bambusa vulgaris var. striata has the highest value viz., one (35.64\%), two $(34.92 \%)$, three $(34.24 \%)$ and four-year-old $(33.71 \%)$ than the control.
Ash content is the indication of silica and foreign materials presence in chips. The ash content ranged between 2.84 per cent (Bambusa polymorpha) and 4.20 per cent (Dendrocalamus strictus) in one-year-old species. In the fifth year ash content ranges between 1.40 per cent (Bambusa balcooa and Bambusa tulda) and 2.50 per cent (Bambusa vulgaris var. vulgaris). The lowest ash content was observed in the five-year age gradation of Bambusa balcooa and Bambusa tulda. Current results reveal that ash content decreases with the increase in the age of the tree.

Lignin percentage in the wood is an indicative of cooking chemical requirement during pulping. In first year, acid insoluble lignin was found to be in the range between 23.46 per cent (Bambusa polymorpha) and 20.60 per cent (Bambusa balcooa). This component was increased with an increase in age. So the highest value is recorded in the five-year age gradations of Dendrocalamus strictus followed by Bambusa bambos. The lowest value was observed in the age gradations of Bambusa balcooa viz., one (20.60\%), two $(22.10 \%)$, three $(22.60 \%)$, four $(23.50 \%)$ and five-year-old (24.80 \%) (Table 3).

Holocellulose constituting cellulose and hemicelluloses is the major portion of fibrous raw material. The one-year-old Bambusa balcooa showed maximum holocellulose content $(66.40 \%)$ in and the minimum was found in one-year-old Bambusa polymorpha $(64.10 \%)$. On the account of different age gradations of various Bamboo species, oneyear age gradations recorded significantly higher hollocellulose content. Among the various bamboo species, the age gradations of Bambusa balcooa has the higher holocellulose content viz., one (66.40\%), two $(67.80 \%)$, three $(68.20 \%)$, four $(68.90 \%)$ and five-year-old $(69.60 \%)$ followed by Bambusa vulgaris var. striata showed the highest value of holocellulose content. 
Table.1 Comparison of physical properties for different bamboo species at different age gradations

\begin{tabular}{|c|c|c|c|c|c|c|c|c|c|c|c|c|c|c|c|}
\hline \multirow{3}{*}{ Species } & \multicolumn{15}{|c|}{ Age in years } \\
\hline & \multicolumn{5}{|c|}{ Moisture (\%) as received } & \multicolumn{5}{|c|}{ Bulk density (OD basis) $\left(\mathrm{kg} \mathrm{m}^{-3}\right)$} & \multicolumn{5}{|c|}{ Basic density (OD basis) $\left(\mathrm{kg} \mathrm{m}^{-3}\right)$} \\
\hline & 1 & 2 & 3 & 4 & 5 & 1 & 2 & 3 & 4 & 5 & 1 & 2 & 3 & 4 & 5 \\
\hline Bambusa vulgaris var. vulgaris & 49.13 & 40.07 & 39.73 & 31.43 & 31.10 & 154.00 & 161.00 & 173.00 & 182.00 & 190.00 & 410.50 & 426.40 & 441.80 & 453.10 & 460.00 \\
\hline Bambusa vulgaris var. striata & 29.68 & 29.43 & 27.82 & 26.47 & 24.35 & 148.00 & 153.00 & 168.00 & 174.00 & 180.00 & 390.00 & 410.00 & 435.00 & 445.00 & 450.00 \\
\hline Bambusa balcooa & 56.86 & 51.46 & 48.35 & 46.78 & 45.01 & 179.00 & 186.00 & 195.00 & 207.00 & 218.00 & 428.00 & 442.00 & 466.00 & 472.00 & 480.90 \\
\hline Bambusa tulda & 42.93 & 39.65 & 36.58 & 34.23 & 31.40 & 186.00 & 194.00 & 206.00 & 212.00 & 225.00 & 431.20 & 446.80 & 468.20 & 475.10 & 482.00 \\
\hline Bambusa polymorpha & 68.14 & 62.48 & 56.85 & 51.78 & 36.14 & 136.00 & 148.00 & 163.00 & 179.00 & 190.00 & 416.70 & 428.40 & 441.60 & 453.90 & 465.10 \\
\hline Dendrocalamus strictus & 49.02 & 48.76 & 38.60 & 37.37 & 31.11 & 181.00 & 189.00 & 196.00 & 203.00 & 210.00 & 432.30 & 448.70 & 458.00 & 469.40 & 480.00 \\
\hline Bambusa bambos & 56.19 & 49.64 & 41.34 & 36.71 & 32.48 & 172.00 & 180.00 & 191.00 & 204.00 & 212.00 & 422.20 & 438.80 & 450.75 & 462.10 & 480.60 \\
\hline
\end{tabular}

Table.2 Comparison of Solubility characters of different bamboo species at different age gradations

\begin{tabular}{|c|c|c|c|c|c|c|c|c|c|c|c|c|c|c|c|}
\hline \multirow{3}{*}{ Species } & \multicolumn{15}{|c|}{ Age in years } \\
\hline & \multicolumn{5}{|c|}{ Alcohol benzene extractive (\%) } & \multicolumn{5}{|c|}{ Hot water solubility (\%) } & \multicolumn{5}{|c|}{$1 \%$ NaOH solubility (\%) } \\
\hline & $\mathbf{1}$ & 2 & 3 & 4 & 5 & 1 & 2 & 3 & 4 & 5 & 1 & 2 & 3 & 4 & 5 \\
\hline Bambusa vulgaris var. vulgaris & 0.24 & 1.01 & 1.57 & 2.28 & 2.44 & 7.95 & 7.12 & 6.2 & 5.48 & 4.1 & 30.2 & 28.5 & 26.8 & 25.6 & 23.2 \\
\hline Bambusa vulgaris var. striata & 1.05 & 2.87 & 3.12 & 3.9 & 4.22 & 8.92 & 6.91 & 5.26 & 3.62 & 1.87 & 35.64 & 34.92 & 34.24 & 33.71 & 33.13 \\
\hline Bambusa balcooa & 0.81 & 0.97 & 1.4 & 1.5 & 2.46 & 6.84 & 5.45 & 4.59 & 2.68 & 2.13 & 28.46 & 27.12 & 25.94 & 23.76 & 23.12 \\
\hline Bambusa tulda & 1.17 & 1.2 & 1.4 & 1.4 & 2.47 & 3.35 & 3.22 & 3.1 & 2.65 & 1.3 & 25.48 & 24.24 & 23.61 & 22.75 & 21.8 \\
\hline Bambusa polymorpha & 0.64 & 1.22 & 1.61 & 2.27 & 2.82 & 9.82 & 8.94 & 8.34 & 7.48 & 6.88 & 23.74 & 22.45 & 21.74 & 20.46 & 18.39 \\
\hline Dendrocalamus strictus & 0.31 & 0.77 & 0.85 & 0.85 & 1.22 & 9.75 & 8.75 & 7.25 & 6.6 & 4.45 & 32.7 & 29.41 & 26.48 & 24.3 & 23.5 \\
\hline Bambusa bambos & 0.55 & 1.28 & 1.35 & 1.7 & 1.78 & 9.2 & 8.14 & 6.8 & 5.46 & 4.82 & 24.33 & 23.48 & 22.35 & 22.15 & 21.54 \\
\hline
\end{tabular}

Table.3 Comparison of chemical properties for different bamboo species at different age gradations

\begin{tabular}{|c|c|c|c|c|c|c|c|c|c|c|c|c|c|c|c|}
\hline \multirow{3}{*}{ Species } & \multicolumn{15}{|c|}{ Age in years } \\
\hline & \multicolumn{5}{|c|}{ Ash content (\%) } & \multicolumn{5}{|c|}{ Acid insoluble lignin (\%) } & \multicolumn{5}{|c|}{ Hollo cellulose (ash corrected) (\%) } \\
\hline & $\mathbf{1}$ & 2 & $\mathbf{3}$ & 4 & 5 & $\mathbf{1}$ & 2 & 3 & 4 & 5 & 1 & 2 & 3 & 4 & 5 \\
\hline Bambusa vulgaris var. vulgaris & 3.40 & 3.00 & 2.80 & 2.60 & 2.50 & 21.60 & 22.80 & 24.10 & 25.00 & 25.80 & 65.60 & 66.40 & 67.10 & 67.20 & 68.00 \\
\hline Bambusa vulgaris var. striata & 3.60 & 3.20 & 2.80 & 2.60 & 2.20 & 21.20 & 22.10 & 23.10 & 23.60 & 25.40 & 66.20 & 67.70 & 68.10 & 68.70 & 69.20 \\
\hline Bambusa balcooa & 3.80 & 3.50 & 3.20 & 2.80 & 1.40 & 20.60 & 22.10 & 22.60 & 23.50 & 24.80 & 66.40 & 67.80 & 68.20 & 68.90 & 69.60 \\
\hline Bambusa tulda & 3.20 & 1.80 & 1.80 & 1.80 & 1.40 & 21.40 & 23.40 & 24.10 & 24.60 & 26.10 & 65.50 & 66.60 & 67.10 & 67.80 & 68.40 \\
\hline Bambusa polymorpha & 2.84 & 2.10 & 1.75 & 1.67 & 1.62 & 23.46 & 24.80 & 25.85 & 26.43 & 27.08 & 64.10 & 64.80 & 65.40 & 66.10 & 66.70 \\
\hline Dendrocalamus strictus & 4.20 & 3.80 & 3.40 & 2.50 & 2.00 & 21.80 & 23.00 & 24.20 & 25.90 & 28.20 & 64.40 & 64.90 & 65.40 & 66.20 & 67.00 \\
\hline Bambusa bambos & 2.86 & 2.10 & 1.90 & 1.60 & 1.45 & 22.20 & 24.30 & 25.70 & 26.60 & 27.50 & 64.20 & 64.80 & 65.40 & 66.60 & 67.00 \\
\hline
\end{tabular}


Fig.1 Ash content of various bamboo species at different age gradations

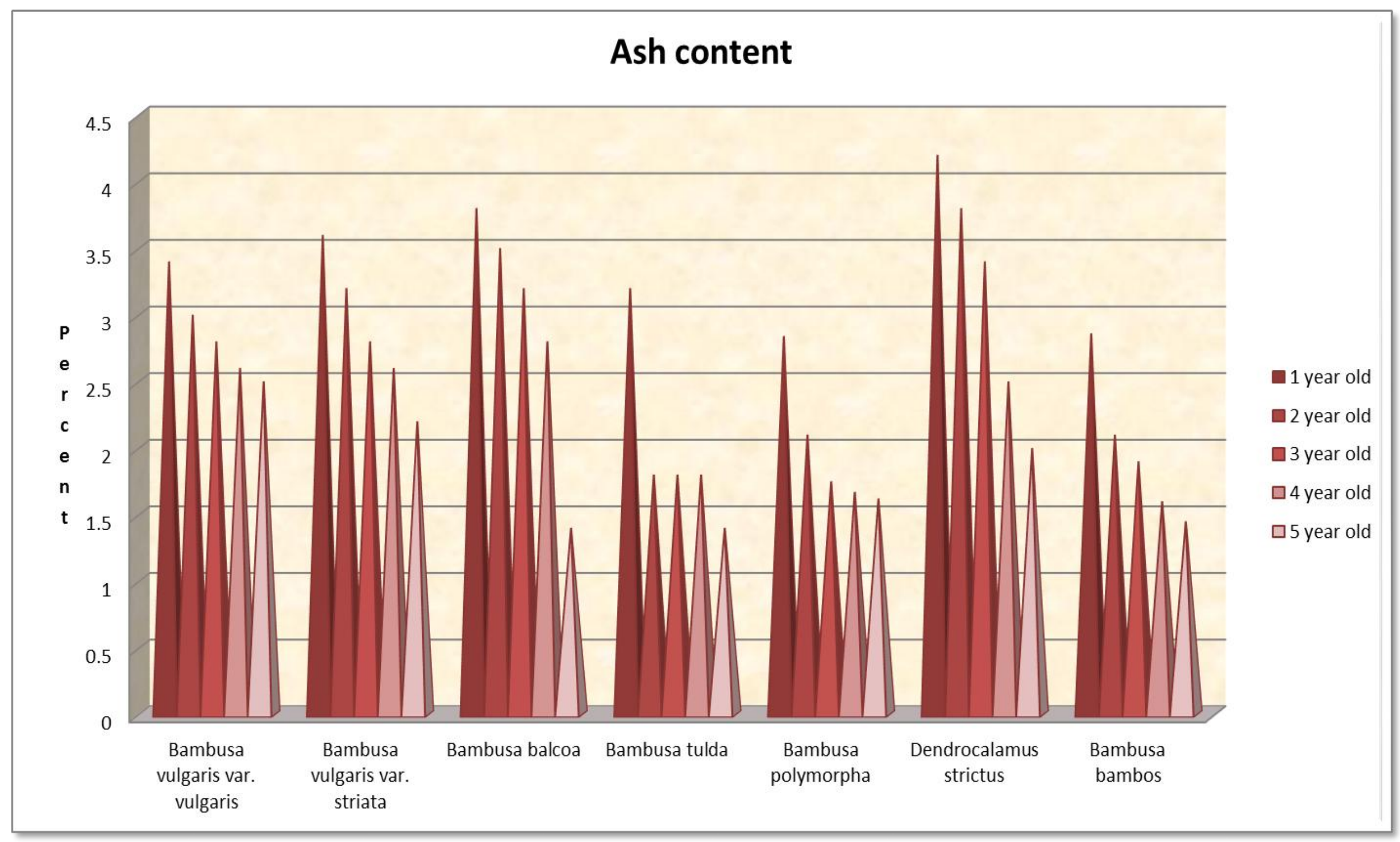


Fig.2 Lignin content of various bamboo species at different age gradations

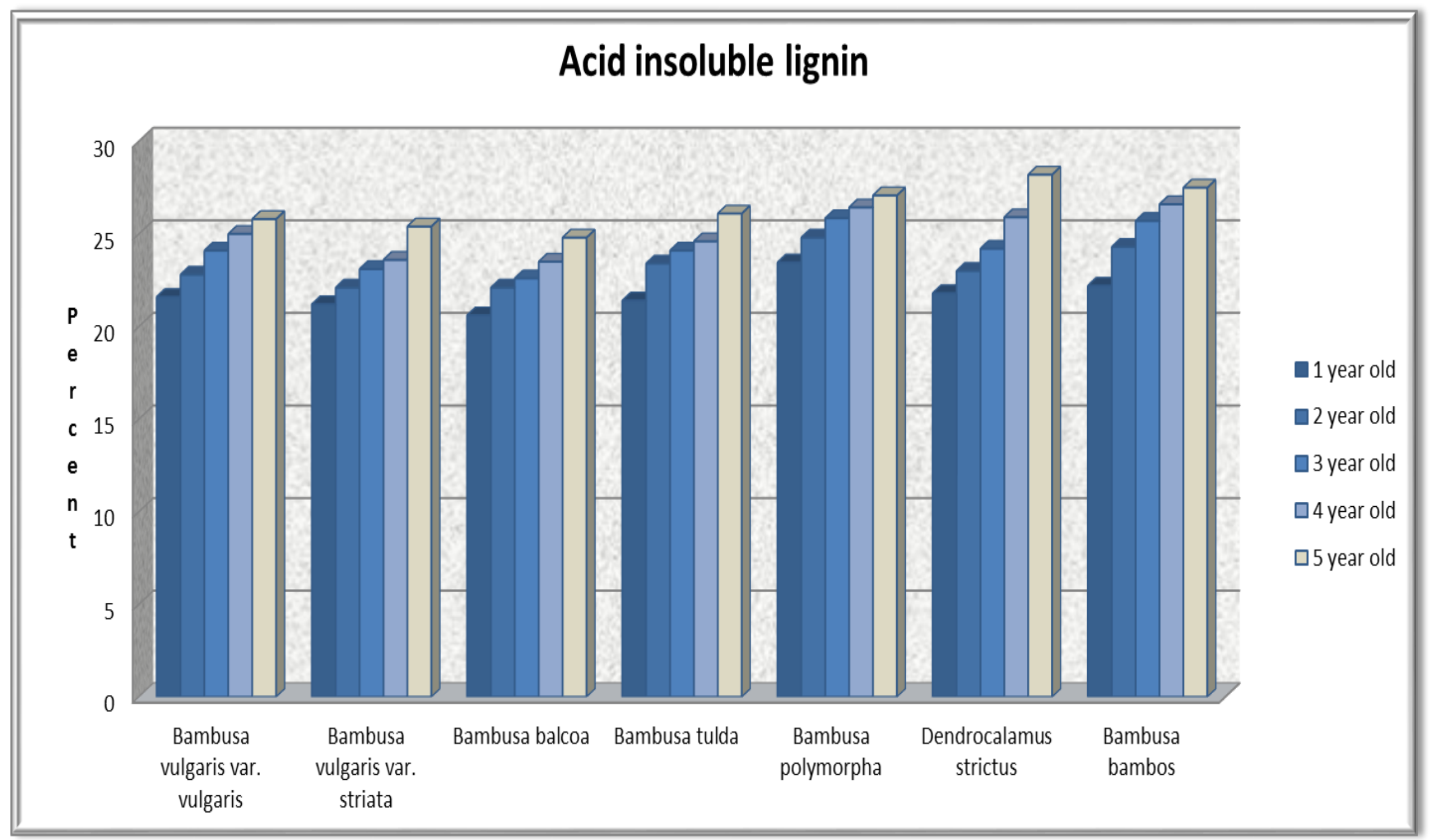


Fig.3 Hollocellulose content of various bamboo species at different age gradations

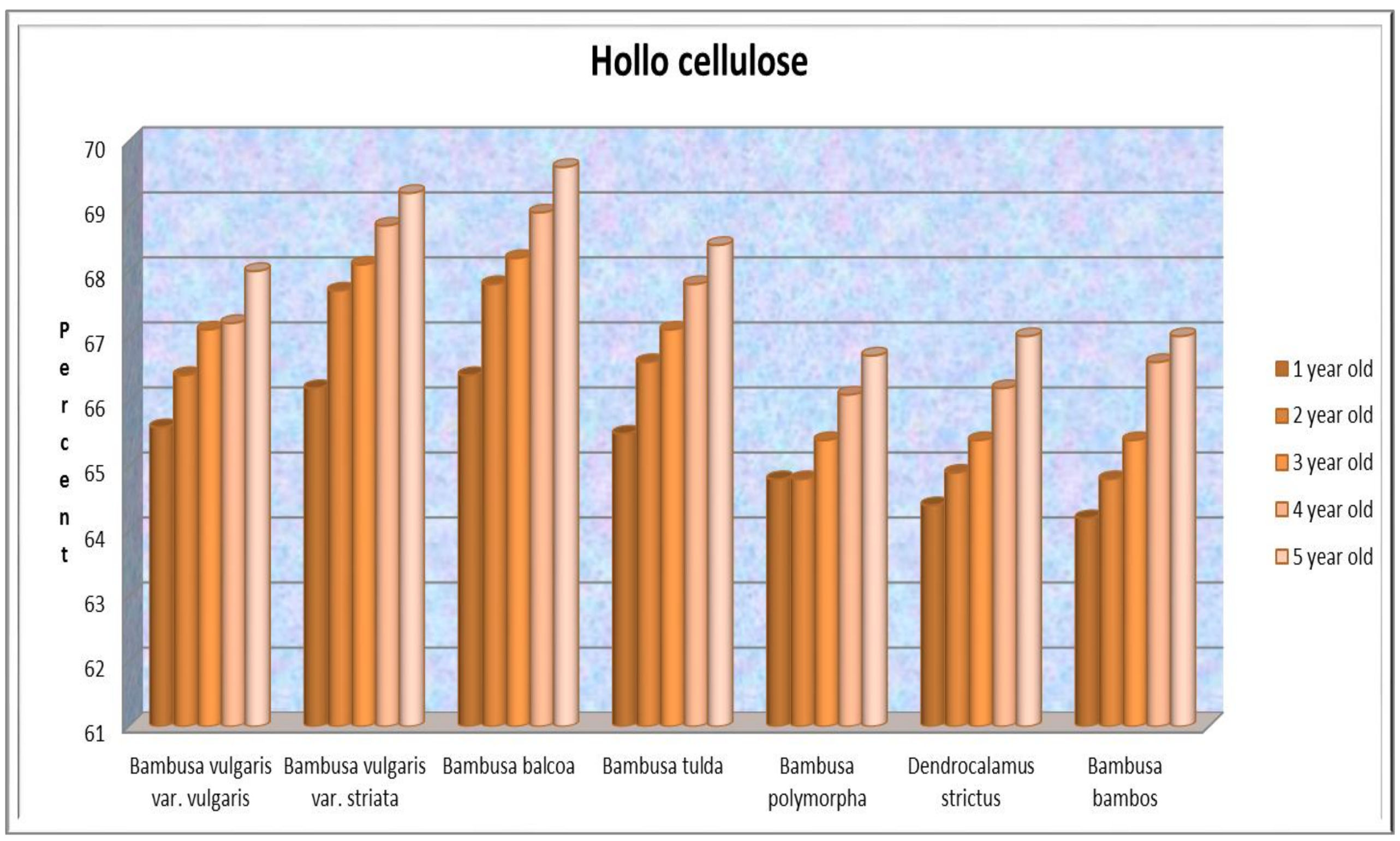


The lowest amount of holocellulose was observed in the age gradations of Bambusa polymorpha viz., one $(64.10 \%)$, two $(64.80$ $\%)$, three $(65.40 \%)$, four $(66.10 \%)$ and fiveyear-old $(66.70 \%)$. This results shows that holocellulose decreases with an increase in age.

\section{Physical properties of wood chips}

The physical properties of wood material particularly basic density, bulk density, wood moisture are highly essential. The role of moisture content on dimensional stability is studied as a basic concern while using any forest products. It is not usually desirable to use the material that experiences rapid moisture changes because moisture affects the physical and mechanical properties of wood materials (Anon., 1992 and Ahmad and Kamke, 2005).

In the current study, the physical properties studied had exhibited variation in all thornless species compared to Bambusa bambos in different age gradations viz., one, two, three, four, five-year-old. The age gradations of Bambusa tulda showed higher bulk density, basic density and lesser moisture content than the Bambusa bambos. Among the different age gradations, five-year-old Bambusa tulda had higher bulk density $\left(225.00 \mathrm{~kg} \mathrm{~m}^{-3}\right)$, basic density (490.60 $\mathrm{kg} \mathrm{m}^{-3}$ ) and lesser moisture content (31.40 \%). Bambusa balcooa also showed higher bulk density $\left(218.00 \mathrm{~kg} \mathrm{~m}^{-3}\right)$ and basic density $\left(480.90 \mathrm{~kg} \mathrm{~m}^{-3}\right)$, which are higher compared to Bambusa bambos (traditional species used by paper industry). Sattar et al., (1990) found higher moisture content in $B$. balcooa compared to $M$. bacciera. The Higher oven dry density and lowest initial moisture content were observed in the oldest culm of 6.5 years. Their means were $680 \mathrm{~kg} \mathrm{~m}^{-3}$ and 48.6 per cent respectively (Hisham et al., 2006). Jamaludin et al., (2002) also found similar trend in 1 to 3-year-old G. scortechinii. The increase of density with age was probably due to thicker lamellated fibre walls and parenchyma cells in older culms (Espiloy, 1987; Liese, 1987 and Abd. Latif et al., 1996).

\section{Chemical properties}

The proximate chemical analysis given an idea of potentiality of raw material for paper making process (Rao et al., 1999). The chemical analysis in terms of ash content recorded was highest in one-year age gradation of $(4.20 \%)$ of Dendrocalamus strictus and lowest in one-year-old age gradation (2.84 \%) of Bambusa polymorpha (Fig. 1). Five-year age gradation shows lowest ash content. Among the various bamboo species five-year age gradation of Bambusa balcooa (1.40 \%) has low ash content, which implies that ash content decreases with the increase in the age of the bamboo species. Li et al., (2007) reported that ash content of one-year-old bamboo was significantly higher than that of three and five-year-old bamboos. Elevated ash content in one-year-old stems may be explained by the higher proportions of silica-rich epidermal tissue and metabolically active vascular tissues that function to mobilize inorganic nutrients to other regions of the plant. The ash content decreased by 1 per cent and 1.6 per cent in Acacia nilotica and Prosopis julifora, respectively for 15-year old trees as compared to 5-year old trees. High contents of ash will negatively impact the chemical recovery process and, therefore, could constitute a serious drawback (Khiari, 2010).

The water and alcohol-benzene soluble substances affect the pulp yield, paper quality and drainage characteristics of paper machine. In the current study, five-year-old Dendrocalamus strictus (1.22 \%) showed lowest alcohol benzene extractive, hot water solubility as compared to Bambusa bambos. 
The five-year-old Bambusa vulgaris var. vulgaris $(2.82 \%)$ wood sample registered highest alcohol benzene extractive (4.22\%) and hot water solubility (33.13\%) when compared to Bambusa bambos. Five year samples showed higher alcohol benzene extractives and lower hot water solubility and $1 \% \mathrm{NaOH}$ solubility. Li et al., (2007) reported that alcohol-toluene extractives showed the largest variation, with average values for each age ranging from 3.2-6.9 per cent. Alcohol-toluene extractives increased significantly with age, with the five-year-old bamboo having the highest average content at 6.9 per cent.

Among the chemical properties, holocellulose is very important because it is a measure of total carbohydrate content of the wood (TAPPI, 2001). The holocellulose constituting cellulose and hemicellulose is the major portion of fibrous raw material.

In current study, among the various bamboo species Bambusa balcooa recorded the highest hollocellulose content and within the different age gradations of Bambusa balcooa, five age gradation $(69.60 \%)$ showed higher value than the other age gradations (Fig. 3). Hisham et al., (2006) reported that holocellulose content slightly increased beyond 3.5 years and higher density in old bamboo probably causes greater contents of holocellulose, lignin, ash and silica. Similar results were observed in Pinus taeda at different age gradation (Mcdonough et al., 2011).

With regard to lignin content, low lignin was observed in the one-year age gradation of Bambusa balcooa (20.60 \%) and higher amount of lignin was recorded in the five-year age gradation of Dendrocalamus strictus (28.20 \%) (Fig. 2). Li et al., (2007) reported that the one-year-old culms had lower holocellulose and lignin contents than the three and five-year-old culms. Bamboo with higher holocellulose and lower lignin content may be better suited for pulp and paper (Escalano, 1973). Hence the superiority of Bambusa balcooa in terms of higher holocellulose and lower lignin content indicated its suitability.

The study was conducted in Forest College and Research Institute, Mettupalayam constitute seven bamboo species as the experimental material with five age gradations and subjected to Physio-chemical characterization. The lowest air dry moisture content of five-year age gradation of Bambusa vulgaris var. striata was found to be nearly 24.35 per cent and one-year-old sample recorded higher moisture content. Five-year age gradation recorded higher Bulk density and basic density which ranged from 180.00 to $225.00 \mathrm{~kg} \mathrm{~m}^{-3}$ and 450.00 to $482.00 \mathrm{~kg} \mathrm{~m}^{-3}$ respectively. Among different species, Bambusa tulda recorded higher bulk density $\left(280 \mathrm{~kg} \mathrm{~m}^{-3}\right)$ and basic density $\left(500.20 \mathrm{~kg} \mathrm{~m}^{-3}\right)$.

Study of proximate analysis showed that the $\mathrm{AB}$ extractives were in the range of 0.24 to 1.17 per cent in the one age gradation and it increased with the increase in age. Holocellulose content was found minimum $(66.40 \%)$ in one-year-old and maximum $(69.60 \%)$ in five-year-old sample of Bambusa balcooa.

It was observed that lowest lignin content existed in the range of 20.60 per cent (oneyear-old sample) to 24.80 per cent (five-yearold sample) in Bambusa balcooa.

Among seven bamboo species evaluated for Physio-chemical, Bambusa balcooa proved superior in terms of physio-chemical properties. Among the different age gradations, five-year-old sample exhibited superiority over other age gradations. 


\section{References}

Abd. Latif, M., O., Arshad, K. Jamaludin and S. Mohd. Hamami, S. 1996. Chemical constituents and physical properties of Bambusa heterostachya. Thailand Journal of Forestry, 15: 14-25.

Abd. Latif, M., W.A. Wan Tarmeze and A. Fauzidah. 1990. Anatomical features and mechanical properties of three Malaysian bamboo. Journal of Tropical Forest Science, 2: 227-234.

Ahmad, M., and F.A. Kamke. 2005. Analysis of Calcutta bamboo for structural composite materials: Physical and mechanical properties. Wood Science and Technology, 39(4): 448-459.

Anonymous, 1992. Advances in pulp and paper research. Indian Council of Forestry Research and Education, Dehra Dun.

Anonymous, 2001. Cultivation and integrated utilization on bamboo in China. China National Bamboo Research Center, Hangzhou.

Espiloy, Z.B., 1987. Physico-mechanical properties and anatomical relationships of some Philippine bamboos. In: Rao, A.N. et al., (Eds.). Recent Research on Bamboo. Proceedings of an International Workshop. 16-14 October 1985, Hangzhou. pp. 257-264.

Haygreen, G.J., and J.L. Bowger. 1982. Forest products and wood science - An introduction. IOWA State University Press, Ames, U.S.A.

Hisham, N.H., S. Othman, H. Rokiah, M. Abd. Latif, S. Ani and Mohd. M. Tamizi. 2006. Characterization of bamboo Gigantochloa scortechinii at different ages. Journal of Tropical Forest Science, 18(4): 236-242.

Jamaludin, K., A. Abd. Jalil and M. Abd. Latif. 2002. Variation of moisture content and density with age and height level in Gigantochloa scortechinii. Journal of Tropical Forest Products,
8(1): 112-114.

Khiari, R., M.F. Mhenni, M.N. Belgacem and E. Mauret. 2010. Chemical composition and pulping of date palm rachis and Posidonia oceanic - A comparison with other wood and non-wood fiber sources. Bioresource Technology, 101: 775-780.

Lal, P., 2000. National forest policy and raw material supplies for wood based industries in India. Indian Forester, 126(4): 351-365.

Li, X.B., T.F. Shupe, G.F. Peter, C.Y. Hse and T.L. Eberhardt. 2007. Chemical changes with maturation of the bamboo species Phyllostachys pubescens. Journal of Tropica1Forest Science, 19(1): 612.

Liese, W., 1987. Anatomy and properties of bamboo. In: Rao, A.N. et al., (Eds.) Proceedings of the International Bamboo Workshop. 6-14 October 1985, Hangzhou. pp. 196-208.

Liese, W., 1997. Structural research issue on bamboo. Special Focus. INBAR 5(1\&2): 27-29.

Liese, W., and G. Weiner. 1996. Ageing of bamboo culms. A review. Wood Science and Technology, 30: 77-89.

Mcdonough, T.J., C.E. Courchene, D.E. White, L. Schimleck and G. Peter. 2011. Effects of loblolly pine tree age and wood properties on linerboardgrade pulp yield and sheet properties: Part 1-Effects on pulp yield. TAPPI J., 9: 45-53.

Negi, S.S., 1996. Bamboos and Canes. Bishen Singh and Mahendra Pal Singh, Dehradun, India.

Rao, R.V., V. Kothiyal, P. Sreevani, S. Shashikala, S. Naithani and S.V. Singh. 1999. Yield and strength properties of pulp of some clones of Eucalyptus tereticornis. Indian Forester, 125(11): 1145-1151.

Sattar, M.A., M.F. Kabir and D.K. Battacharjee. 1994. Effect of age and 
height position of Muli (Melocanna baccifera) and Borak (Bambusa balcooa) bamboos on their physical and mechanical properties. FORSPA No. 6 . IDRC/FAO/UNDP. pp. 183-187.

Sattar, M.A., M.F. Kabir and D.K. Bhattacharjee. 1990. Effect of age and height positions of muli (Melocanna baccifera) and borak (Bambusa balcooa) bamboos on their physical and mechanical properties. Bangladesh J. For. Sci., 19: 29-37.

TAPPI, 1980. Standard and suggested methods. Technical Association of Pulp and Paper Industry, New York. pp. 200265.
TAPPI, 2001. Laboratory manual on testing procedures. Published by the Director, Central Pulp and Paper Research Institute, Saharanpur (U.P.). TM 1-A9.

Widjaja, E.A., and Z. Risyad. 1987. Anatomical properties of some bamboo utilized in Indonesia. In: Rao et al., (Eds.). Recent Research on Bamboo. Proceedings of an International Workshop. 6-14 October 1985. Hangzhou. pp. 224-246.

Zhou, F., 1981. Studies on physical and mechanical properties of bamboo woods. Journal Nanjing Technology College of Forestry Product, 2: 1-32.

\section{How to cite this article:}

Thirunirai Selvan, R., K.T. Parthiban and Umesh Khanna, S. 2017. Physio-Chemical Properties of Bamboo Genetic Resources at Various Age Gradations. Int.J.Curr.Microbiol.App.Sci. 6(9): 1671-1681. doi: https://doi.org/10.20546/ijcmas.2017.609.205 